\title{
EVALUASI PENGGUNAAN OBAT ANTIHIPERTENSI PADA PASIEN LANJUT USIA DI RUMAH SAKIT UMUM IMELDA PEKERJA INDONESIA MEDAN
}

\author{
Roby Gultom ${ }^{1}$, Aminah Harahap ${ }^{2}$ \\ Universitas Imelda Medan
}

\begin{tabular}{l}
\hline \hline Article Info \\
\hline Article history: \\
Received Aug 27, 2021 \\
Revised Sept 24, 2021 \\
Accepted Sept 27, 2021 \\
\hline
\end{tabular}

\section{Keywords:}

Evaluation

Elderly

Antihypertensive

\begin{abstract}
Hypertension is called the "silent killer" which is a risk factor for heart disease, stroke and kidney failure. High blood pressure that can not protect properly will increase the mortality and morbidity. Elderly patients aged $\geq 60$ years, most of them already have hypertension and even have experienced the risk factors caused by hypertension. The goal of therapy is not to exacerbate organ damage and reduce mortality and improve patient quality so that evaluation is necessary, especially for the selection of antihypertensive drugs. This study aims to meet the suitability of the types of antihypertensive drugs given to elderly patients at the General Hospital of Imelda Pekerja Indonesia Medan with the standard of hypertension treatment. Research data collection was carried out in a retrospective manner in the period January-April 2020. Data were analyzed using the SPSS 21, JNC VIII (2016) method. There were 9 patients $(28.1 \%)$, the use of antihypertensive drugs in elderly patients who did not comply with the standard recommendations for hypertension therapy and 23 patients $(71.9 \%)$ who used antihypertensive drugs in accordance with JNC VIII standards.
\end{abstract}

This is an open access article under the CC BY-SAlicense.

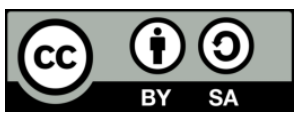

\section{Corresponding Author:}

Roby Gultom,

Program Studi S1 Farmasi,

Universitas Imelda Medan,

Jl. Bilal No. 52 Kelurahan Pulo Brayan Darat I Kecamatan Medan Timur, Medan - Sumatera Utara.

Email: roby.gultom@gmail.com

\section{INTRODUCTION}

Hipertensi adalah penyakit kronis degeneratif yang mengalami peningkatan sehingga menjadi penyebab utama mortalitas dan morbiditas di Indonesia, penatalaksanaan penyakit ini merupakan intervensi yang sangat umum dilakukan di berbagai tingkat fasilitas kesehatan (Susilowati et al., 2017). Hipertensi dialami jika tekanan darah pada sitolik $>140 \mathrm{mmHg}$ dan diastolik > $90 \mathrm{mmHg}$ dengan dua kali pengukuran selama selang waktu lima menit dalam keadaan istirahat. Hipertensi dapat menyebabkan penyakit jantung koroner, gagal jantung, stroke, penyakit ginjal kronik, kerusakan retina maupun penyakit vaskuler perifer (Yulanda \& Lisiswanti, 2017). Menurut (Muhadi, 2016), hipertensi pada lanjut usia merupakan perubahan target tekanan darah sistolik pada pasien berusia 60 tahun ke atas menjadi $<150 \mathrm{mmHg}$. 
Hipertensi dapat terjadi pada lanjut usia, seseorang yang telah mencapai usia 60 tahun keatas dapat dikatakan lanjut usia (Permenkes RI, 2015). Berdasarkan hasil Riskesdas tahun 2013 penyakit terbanyak pada lanjut usia adalah hipertensi yaitu sebanyak $57,6 \%$ disusul dengan artritis $(51,9 \%)$ dan stroke $(46,1 \%)$. Hipertensi dialami pada usia 51-75 tahun sebanyak 10.015 pasien $(69,62 \%)$. Hipertensi paling banyak di derita pada perempuan 8.642 pasien $(59,77 \%)$ sedangkan pada laki-laki 5.818 pasien $(40,23 \%)$ (Ratnasari et al., 2017).

Obat antihipertensi terbagi menjadi tiga golongan yaitu golongan ARB (Angiotensin Receptor Blocker), CCB (Calcium Channel Blocker), dan ACEI (Angiotensin Converting Enzyme Inhibitor) (Supraptia et al., 2014).

Menurut penelitian (Khotimah, 2016), dari 65 data rekam medik pasien yang telah di evaluasi kesesuaiannya dengan JNC VIII tahun 2013, penggunaan obat antihipertensi tunggal sebanyak $43,08 \%$ dan obat antihipertensi kombinasi sebanyak 56,92\%. Penggunaan obat antihipertensi tunggal yang paling banyak yaitu golongaan CCB sebesar 56,67\% dan obat antihipertensi kombinasi yang paling banyak digunakan yaitu golongan CCB dan ARB sebesar $10 \%$ (Alaydrus \& Toding, 2019).

Golongan CCB yang paling banyak digunakan pada pasien lanjut usia adalah amlodipin. Amlodipin lebih efektif untuk hipertensi sistolik terisolasi dan mempunyai kemampuan sangat baik untuk menurunkan tekanan darah dalam waktu singkat(Wiharti \& Astuti, 2017). Menurut penelitian Budi Supraptia dkk, dari 350 sampel menunjukkan bahwa hipertensi paling sering ditemukan pada usia 66-74 tahun sebanyak 50,9\%, lebih dari $60 \%$ pasien menerima lebih dari satu terapi antihipertensi.

Rumah Sakit merupakan kegiatan yang meliputi pelayanan rawat jalan, rawat inap, dan dan gawat darurat(Permenkes RI, 2019).Rumah Sakit memiliki pelayanan penunjang medik seperti polifarmasi. Polifarmasi melayani resep misalnya pada pasien rawat jalan. Peresepan obat antihipertensi pada pasien rawat jalan Rumah Sakit Imelda Pekerja Indonesia Medan, sebanyak 63 dalam periode Januari-April peresepan obat tersebut diberikan berdasarkan kondisi pasien. Obat antihipertesi yang diberikan yaitu obat-obat golongan ARB, CCB, ACEI, $\beta$-Blocker, dan Diuretik.

Dari permasalahan tersebut maka perlu dilakukan evaluasi penggunaan obat antihipertensi yang paling banyak digunakan pada pasien lanjut usia rawat jalan di Rumah Sakit Umum Imelda Pekerja Indonesia Medan pada tahun 2020.

\section{RESEARCH METHOD}

Pendekatan penelitian yang digunakan dalam penelitian ini adalah penelitian deskriptif yang bersifat retrospektif (Nurlaily \& Pratiwi, 2012). Populasi dalam penelitian ini data rekam medik pasien rawat jalan yang didiagnosa penyakit hipertensi dan menjalani pengobatan di Rumah Sakit Umum Imelda Pekerja Indonesia Medan sebanyak 32 pasien. Sampel penelitian yaitu 32 data rekam medik pasien yang memenuhi kriteria inklusi di Rumah Sakit Umum Imelda Pekerja Indonesia Medan periode Januari-April 2020. Penelitian ini dilakukan di Rumah Sakit Umum Imelda Pekerja Indonesia Medan periode Januari-April 2020. Analisis data yang memuat nomor rekam medik, umur, jenis kelamin, ruang rawat jalan, diagnosa dan antihipertensi dengan menggunakan program microsoft exel dan diolah dengan bantuan aplikasi pengolah data SPSS 21 .

\section{RESULTS AND ANALYSIS}

\section{Karakteristik Pasien Rawat Jalan}

Penelitian ini dilakukan sesuai dengan etika penelitian salah satunya dengan menjaga kerahasiaan sumber informasi seperti tidak mencantumkan nama pasien hanya di beri inisial dan tidak menampilkan nomor rekam medis yang digunakan dalam penelitian ini. Penelitian ini menggunakan 32 data rekam medis yang telah melewati proses ekslusi dan inklusi. Jumlah sampel penelitian ini telah memenuhi standar karena telah memenuhi jumlah sampel minimum yaitu 32 sampel (Sugiyono, 2012). 
Tabel 1. Karakteristik Demografi Pasien Lanjut Usia Rawat Jalan Di Rumah Sakit Umum Imelda Pekerja Indonesia Medan Berdasarkan Usia

\begin{tabular}{cccc}
\hline No. & Usia & Jumlah Pasien & Persentase \% \\
\hline 1. & 61 & 4 & 12,5 \\
\hline 2. & 62 & 3 & 9,4 \\
\hline 3. & 63 & 2 & 6,3 \\
\hline 4. & 64 & 3 & 9,4 \\
\hline 5. & 65 & 3 & 9,4 \\
\hline 6. & 66 & 3 & 9,4 \\
\hline 7. & 67 & 4 & 12,5 \\
\hline 8. & 68 & 3 & 9,4 \\
\hline 9. & 71 & 2 & 6,3 \\
\hline 10 & 73 & 2 & 6,3 \\
\hline 11. & 79 & 1 & 3,1 \\
\hline 12. & 80 & 1 & 3,1 \\
\hline 13. & 84 & 1 & 3,1 \\
\hline \multicolumn{2}{c}{ Total } & $\mathbf{3 2}$ & $\mathbf{1 0 0 , 0}$ \\
\hline
\end{tabular}

Karakteristik demografi pada pasien lanjut usia berdasarkan umur pada tabel 1 pada umur pasien 61 tahun terdapat 4 pasien (12,5\%), 62 tahun ada 3 pasien $(9,4 \%), 63$ tahun ada 2 pasien $(6,3 \%), 64$ tahun ada 3 pasien $(9,4 \%), 65$ tahun ada 3 pasien $(9,4 \%), 66$ tahun ada 3 pasien $(9,4 \%)$, 67 tahun ada 4 pasien (12,5\%), 68 tahun ada 3 pasien (9,4\%), 71 tahun ada 2 pasien $(6,3 \%), 73$ tahun ada 2 pasien (6,3\%), 79 tahun ada 1 pasien $(3,1 \%), 80$ tahun ada 1 pasien $(3,1 \%), 84$ tahun ada $(3,1 \%)$. Berdasarkan pengelompokan umur pasien lanjut usia yang paling banyak mengalami hipertensi dan menggunakan obat antihipertensi adalah pasien dengan umur 61 dan 67 .

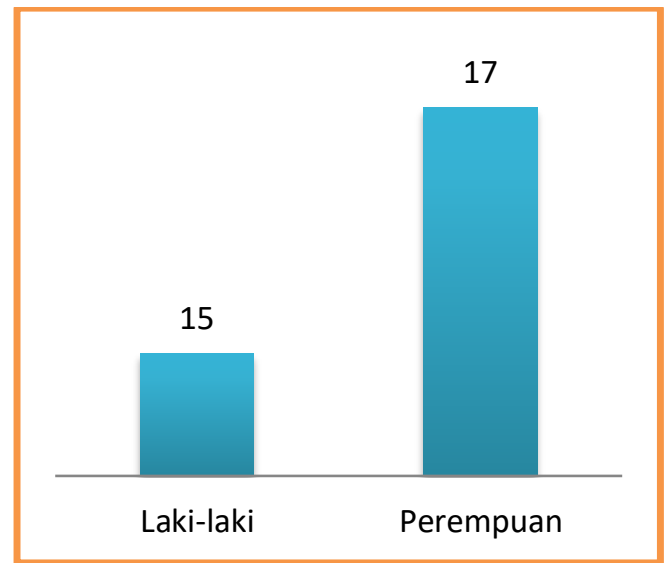

\section{Gambar 1. Karakteristik Demografi Pasien Lanjut Usia Rawat Jalan Di Rumah Sakit Umum} Imelda Pekerja Indonesia Medan Berdasarkan Jenis Kelamin

Karakteristik demografi pada pasien lanjut usia berdasarkan jenis kelamin pada gambar 1 terdapat 15 pasien $(46,9 \%)$ laki-laki dan 17 pasien $(53,1 \%)$ perempuan. Berdasarkan pengelompokan jenis kelamin, pasien lanjut usia yangpaling banyak mengalami hipertensi dan menggunakan obat antihipertensi adalah pasien perempuan. Menurut penelitian (Wiharti \& Astuti, 2017). Pasien hipertensi berjenis kelamin perempuan lebih banyak dari laki-laki yaitu sebesar 59\%. Hal ini disebabkan oleh faktor psikologis. Perempuan lebih sering menderita depresi dibanding laki-laki. Depresi atau stres dapat dianggap sebagai faktor penyebab hipertensi karena stres dapat menyebabkan hiperaktivitas sistem saraf simpatis dan menyebabkan meningkatnya tekanan darah karena sekresi katekolamin meningkat. 
Tabel 2. Distribusi Penggunaan Obat Antihipertensi Terapi Tunggal Pada Pasien Usia Lanjut Rawat Jalan Di Rumah Sakit Umum Imelda Pekerja Indonesia Medan

\begin{tabular}{ccc}
\hline Terapi Tunggal & Nomor Pasien & Jumlah Pasien \\
\hline Amlodipin (CCB) & $3,6,9,11,12,14$, & 11 \\
& $16,20,23,24,25$, & \\
\hline Candesartan (ARB) & $28,5,31,32$. & 4 \\
\hline \multicolumn{2}{c}{ Total } & 15 \\
\hline \multicolumn{2}{c}{ Persentase (\%) } & $47 \%$ \\
\hline
\end{tabular}

Tabel 3. Distribusi Penggunaan Obat Antihipertensi Terapi Kombinasi Pada Pasien Usia Lanjut Rawat Jalan Di Rumah Sakit Umum Imelda Pekerja Indonesia Medan

\begin{tabular}{|c|c|c|}
\hline Terapi Kombinasi & Nomor Pasien & Jumlah Pasien \\
\hline $\begin{array}{l}\text { Amlodipin }(\mathrm{CCB})+ \\
\text { Valsartan }(\mathrm{ARB})\end{array}$ & $1,19,26$ & 3 \\
\hline $\begin{array}{l}\text { Amlodipin }(\mathrm{CCB})+ \\
\text { Candesartan }(\mathrm{ARB})\end{array}$ & 7,27 & 2 \\
\hline $\begin{array}{l}\text { Candesartan }(\mathrm{ARB})+ \\
\text { Nipedipin }(\mathrm{CCB})\end{array}$ & 2,15 & 2 \\
\hline $\begin{array}{l}\text { Candesartan (ARB) + } \\
\text { Amlodipin }(\mathrm{CCB})+ \\
\text { Furosemid (Duretik) }\end{array}$ & 4 & 1 \\
\hline $\begin{array}{l}\text { Nipedipin }(\mathrm{CCB})+ \\
\text { Spironolakton }(\text { Diuretik })+ \\
\text { Valsartan }(\mathrm{ARB})\end{array}$ & 17 & 1 \\
\hline $\begin{array}{l}\text { Furosemid (Diuretik) + } \\
\text { Ramipril (ACEI) }\end{array}$ & 10 & 1 \\
\hline $\begin{array}{l}\text { Nipedipin }(\mathrm{CCB})+ \\
\text { Spironolakton (Diuretik) }\end{array}$ & 29 & 1 \\
\hline $\begin{array}{l}\text { Candesartan (ARB) + } \\
\text { Valsartan }(\mathrm{ARB})\end{array}$ & 30 & 1 \\
\hline $\begin{array}{l}\text { Furosemid (Diuretik) + } \\
\text { Spironolakton (Diuretik) }\end{array}$ & 18,21 & 2 \\
\hline $\begin{array}{l}\text { Amlodipin }(\mathrm{CCB})+ \\
\text { Furosemid (Diuretik) + } \\
\text { Spironolakton (Diuretik) }\end{array}$ & 13 & 1 \\
\hline $\begin{array}{l}\text { Candesartan (ARB) + } \\
\text { Furosemid (Diuretik) + } \\
\text { Spironolakton (Diuretik) }\end{array}$ & 8 & 1 \\
\hline $\begin{array}{l}\text { Amlodipin }(\mathrm{CCB})+ \\
\text { Furosemid (Diuretik) + } \\
\text { Valsartan }(\mathrm{ARB})\end{array}$ & 22 & 1 \\
\hline \multicolumn{2}{|c|}{ Total } & 17 \\
\hline Persentas & & $53 \%$ \\
\hline
\end{tabular}

Berdasarkan tabel 2 dan tabel 3 penelitian ini, terapi antihipertensi yang digunakan di Rumah Sakit Umum Imelda Pekerja Indonesia Medan terapi kombinasi sebanyak 17 pasien, ARB dan CCB sebanyak 7 pasien, ARB dan ARB sebanyak 1 pasien, ARB + Diuretik + Diuretik sebanyak 2 pasien, $\mathrm{CCB}+$ Diuretik + Diuretik sebanyak 1 pasien, $\mathrm{CCB}+$ Diuretik + ARB sebanyak 3 pasien, Diuretik dan ACEI sebanyak 1 orang, CCB dan Diuretik sebanyak 1 pasien, Diuretik dan Diuretik sebanyak 1 pasien. Kombinasi terapi yang paling banyak digunakan adalah golongan ARB dan CCB 21,9\% efeksamping yang lebih rendah diantara antihipertensi yang lain. Hal ini sesuai dengan penelitian (Wulandari, 2019) yang menjelaskan bahwa ACEI juga baik dalam menghambat efek angiotensinogen namun dapat menimbulkan efek samping yaitu batuk kering.

\section{Evaluasi Penggunaan Obat Antihipertensi}

Obat antihipertensi di evaluasi dengan melihat kesesuaian penggunaan standar JNC VIII tahun 2016. Kesesuaian penggunaan obat antihipertensi dalam penelitian ini yaitu saat jenis obat 
yang diberikan kepada pasien lanjut usia sesuai dengan standar JNC VIII. Penggunaan antihipertensi di Rumah Sakit Umum Imelda Pekerja Indonesia Medan sudah sesuai dengan standar JNC VIII, itu dapat dilihat dari data penggunaan antihipertensi terbanyak adalah amlodipine dan terapi kombinasi yang paling banyak adalah ARB dan CCB.

Tabel 3. Evaluasi Penggunaan Obat Antihipertensi Di Rumah Sakit Umum Imelda Pekerja Indonesia Medan

\begin{tabular}{lcc}
\hline $\begin{array}{c}\text { Keterangan } \\
\text { Jenis Obat }\end{array}$ & $\begin{array}{c}\text { Jumlah Pasien } \\
\mathbf{N = 3 2}\end{array}$ & Persentase \% \\
\hline Kesesuaian & 23 & $71,9 \%$ \\
\hline Ketidaksesuaian & 9 & $28,1 \%$ \\
\hline menemukan sebanyak 9 pasien $(28,1 \%)$ & yang mendapatkan obat tidak sesua
\end{tabular}

Penelitian ini menemukan sebanyak 9 pasien $(28,1 \%)$ yang mendapatkan obat tidak sesuai dengan standar terapi yaitu pasien nomor $4,8,10,13,17,18,21,22,29$. Berdasarkan tabel 3 sebanyak 23 pasien $(71,9 \%)$ telah mendapatkan obat sesuai dengan standar terapi JNC VIII.

\section{CONCLUSION}

Berdasarkan hasil penelitian yang telah dilakukan di Rumah Sakit Umum Imelda Pekerja Indonesia Medan kepada pasien penderita hipertensi dapat disimpulkan bahwa hasil penelitian menunjukkan bahwa pasien yang paling banyak menggunakan obat antihipertensi terapi tunggal adalah golongan CCB yaitu amlodipine sebanyak 11 pasien (34,3\%). Terapi kombinasi yang paling banyak digunakan adalah golongan ARB dan CCB 21,9\%. Hasil penelitian menunjukkan bahwa terdapat 23 pasien $(71,9 \%)$ yang mendapatkan terapi yang sesuai dan 9 pasien $(28,1 \%)$ yang mendapatkan terapi tidak sesuai dengan rekomendasi standar terapi hipertensi JNC VIII (2016).

\section{REFERENCES}

Alaydrus, S., \& Toding, A. (2019). Pola Penggunaan Obat Hipertensi Pada Pasien Geriatri Berdasarkan Tepat Dosis, Tepat Pasien Dan Tepat Obat Di Rumah Sakit Anutapura Palu Tahun 2019. Jurnal Mandala Pharmacon Indonesia, 5(2), 65-73. https://doi.org/https://doi.org/10.35311/jmpi.v5i02.46

Khotimah, K. (2016). Skrining Fitokimia dan Identifikasi Metabolit Sekunder Senyawa Karpain Pada Ekstrak Metanol Daun Carica pubescens Lenne \& K. Koch Dengan LC/MS (Liquid Chromatograph-tandem Mass Spectrometry). Universitas Islam Negeri (UIN) Maulana Malik Ibrahim Malang.

Muhadi. (2016). JNC 8: Evidence-based Guideline Penanganan Pasien Hipertensi Dewasa. CDK: Cermin Dunia Kedokteran, $43 \quad$ (1), 54-59. http://www.cdkjournal.com/index.php/CDK/article/view/11

Nurlaily, A. P., \& Pratiwi, A. (2012). Gambaran Pola Asuh Skizofrenia Katatonik (Studi Retrospektif) Di Wilayah Karisidenan Surakarta. Publikasi Ilmiah, 5(4), 173-179. https://publikasiilmiah.ums.ac.id/handle/11617/3684

Permenkes RI. (2015). Permenkes RI No 67: Penyelenggaraan Pelayanan Kesehatan Lanjut Usia di Pusat Kesehatan Masyarakat. Jakarta: Kemenkes RI.

Permenkes RI. (2019). Permenkes RI No 30 Tentang Klasifikasi dan Perizinan Rumah Sakit. Jakarta: Kemenkes RI.

Ratnasari, D., Mediastini, F. X. E., \& K, I. D. (2017). Pola Peresepan Obat Antihipertensi Pasien BPJS yang Diresepkan Dokter Keluarga di Apotek Kabupaten Kendal Periode JanuariDesember 2016. Cendekia Journal of Pharmacy, 1(1). https://cjp.jurnal.stikescendekiautamakudus.ac.id/index.php/cjp/article/view/7

Sugiyono. (2012). Metode Penelitian Kuantitatif Kualitatif dan R\&B. Bandung: Alfabeta.

Supraptia, B., Nilamsari, W. P., Hapsari, P. P., Muzayana, H. A., \& Firdausi, H. (2014). Permasalahan Terkait Obat Antihipertensi pada Pasien Usia Lanjut di Poli Geriatri RSUD Dr.Soetomo, Surabaya. Jurnal Farmasi Dan Ilmu Kefarmasian Indonesia, 1(2), 36-41. http://journal.unair.ac.id/download-fullpapers-jfik3cd995968bfull.pdf

Susilowati, A., Risnawati, C., Zaenurrohmah, \& Rachmayanti. (2017). Gambaran Pola Pengobatan Hipertensi di Puskesmas Berbah Sleman Yogyakarta Bulan Januari 2017. Jurnal Kefarmasian 
Akfarindo, 2(1), 25. http://jofar.afi.ac.id/index.php/jofar/article/view/18

Wiharti, S. D., \& Astuti, N. (2017). GAMBARAN POLA PERESEPAN HIPERTENSI PADA PASIEN GERIATRI DI PUSKESMAS GONDOKUSUMAN I PERIODE AGUSTUS 2016. Jurnal Kefarmasian Akfarindo, 2(2). http://jofar.afi.ac.id/index.php/jofar/article/view/19

Wulandari, T. (2019). Pola Penggunaan Kombinasi Dua Obat Antihipertensi pada Pasien Hipertensi. JURNAL ILKES (Jurnal Ilmu Kesehatan), 10(1). https://doi.org/https://doi.org/10.35966/ilkes.v10i1.116

Yulanda, G., \& Lisiswanti, R. (2017). PENATALAKSANAAN HIPERTENSI PRIMER. MEDICAL JOURNAL OF LAMPUNG UNIVERSITY, 6(1), 25-33. https://juke.kedokteran.unila.ac.id/index.php/majority/article/view/1526 